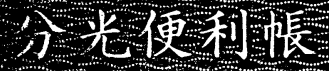

\section{リュードベリ原子のレーザー・マイ クロ波二重共鳴イオン化分光}

波長可変色素レーザーを用いた原子・分子の量子状態 選択的な励起が可能になり，またそれに伴って様々な分 光技術が開発された結果, 高励起 Rydberg 状態に関す る研究が急速に進展した. 特に中性原子については高 励起 Rydberg 準位のエネルギーや準位構造, 寿命など の物理量の測定や1), Rydberg 原子と電磁場との相互作 用, 他粒子との衝突現象に関する研究等が多数報告され て拈り，またそれらの詳細な理論的解析も行われている. しかしながら, 特に高励起 Rydberg 状態の高分解能分 光を主眼としている研究例は意外飞少ない, Rydberg 原
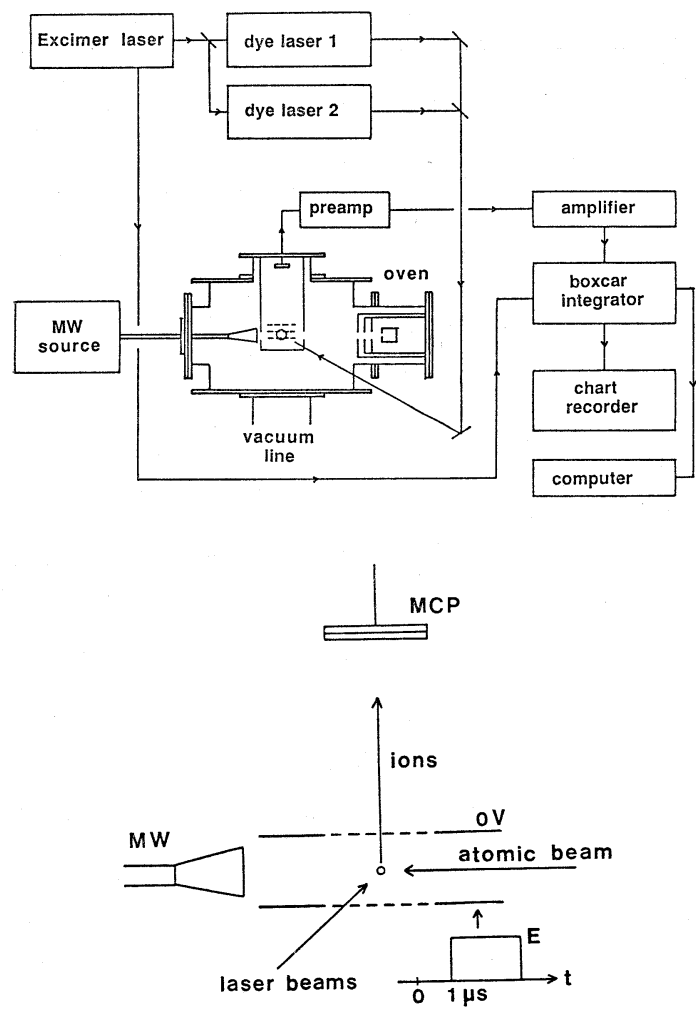

図 1 実験装置の概略図，(a) 全体図，(b) 励起・ イオン化領域.

* Laser-Microwave Double Resonance Ionization Spectroscopy of Rydberg Atoms
子は非常に長寿命であるため，そのスペクトルを高分解 能で測定することによって，他の励起準位との電子配置 間相互作用や励起電子とイオン芯との相互作用等関す る詳細な知見を得ることが可能であり, 興味ある研究結 果を期待することができる.

この様な Rydberg 原子の高分解能分光を目的とする 測定法の一つに, レーザー・マイクロ波二重共鳴分光法 (Double resonance spectroscopy) がある ${ }^{2)}$.この方法 では Rydberg 準位間のマイクロ波遷移を測定するた め, スペクトル分解能は原理的に Rydberg 原子とマイ ク口波との相互作用時間によって決定されることにな り，他の方法に比べて格段に高い分解能を得ることが可 能である. 現在, 我々は $\mathrm{Yb}$ 原子 $\left(\mathrm{Yb} \mathrm{I} 4 \mathrm{f}^{14} 6 \mathrm{~s}^{2}{ }^{1} \mathrm{~S}_{0}\right)$ の イオン化限界（Yb II $4 \mathrm{f}^{14} 6 \mathrm{~s} \quad{ }^{2} \mathrm{~S}_{1 / 2}$ ) に収斂する $6 \mathrm{snl}$ Rydberg 系列準位が $\mathrm{f}^{17}$ 軌道電子の励起等によって生ず る多数の準位から様々な掑動を受ける点に興味を持ち， その高励起 Rydberg 準位のレーザー・マイクロ波二重 共鳴イオン化分光実験を進めている．以下その手法を簡 単に紹介する.

図 1 亿実験装置の概略を示す。 $\mathrm{XeCl}$ エキシマレーザ 一励起の 2 台のパルス色素レーザーを用いて基底状態の $\mathrm{Yb}$ 原子 $\left(4 \mathrm{f}^{14} 6 \mathrm{~s}^{2}{ }^{1} \mathrm{~S}_{0}\right)$ を中間準位 $\left(6 \mathrm{~s} 6 \mathrm{p}^{1}{ }^{1} \mathrm{P}_{1}{ }^{\circ}\right)$ を経 て $6 \mathrm{snl}(1=0,2 \mathrm{n}=34 \sim 55)$ Rydberg 系列隼位の 1 つに励起する. 次にマイクロ波の周波数を掃引しながら 励起原子を照射することによって他の Rydberg 準位へ の共鳴遷移を測定する. マイクロ波源には約 10 個のミ リ波クライストロン $(18 \mathrm{GHz} \sim 78 \mathrm{GHz})$ を使用してい る.この場合, マイクロ波遷移の測定には, 検出感度が 高いことや状態選択的な検出が可能であるなどの優れた 特徽をるつ電界による選択的イオン化 (Selective field ionization) 法を用いている. 具体的には，レーザーパ ルス照射の数 $\mu \mathrm{s}$ 後に適当な強度のパルス電場（ 6600 $\mathrm{V} / \mathrm{cm}$ )を印加することによってマイクロ波遷移の終状 態のみを選択的に電離し，生じたイオンをマイクロチャ ンネルプレートで検出する (図 1(b)). 更にイオン信号 をボックスカー積分器で積算することでイオン化スペク トルの記録を行っている.

図 2 《は $6 \mathrm{~s} 34 \mathrm{p}{ }^{3} \mathrm{P}_{1}{ }^{\circ}-6 \mathrm{~s} 34 \mathrm{~s}{ }^{1} \mathrm{~S}_{0}$ 遷移のスペクトル を示す。この場合スペクトルの幅や周波数に影響を与え る原因として, 自然幅の他にドップラー幅, 黑体輻射, 飽和拡がり，マイクロ波との相互作用時間，クライスト ロンの安定性, 及び励起・イオン化領域存在する微弱 な電場，磁場などを挙げることができる，特にドップラ 一幅 $\Delta \nu_{D}$ はマイクロ波の周波数に比例するため非常に 小さな值となり（この遷移の場合 $\Delta \nu_{D} \sim 50 \mathrm{kHz}$ (F.W. 


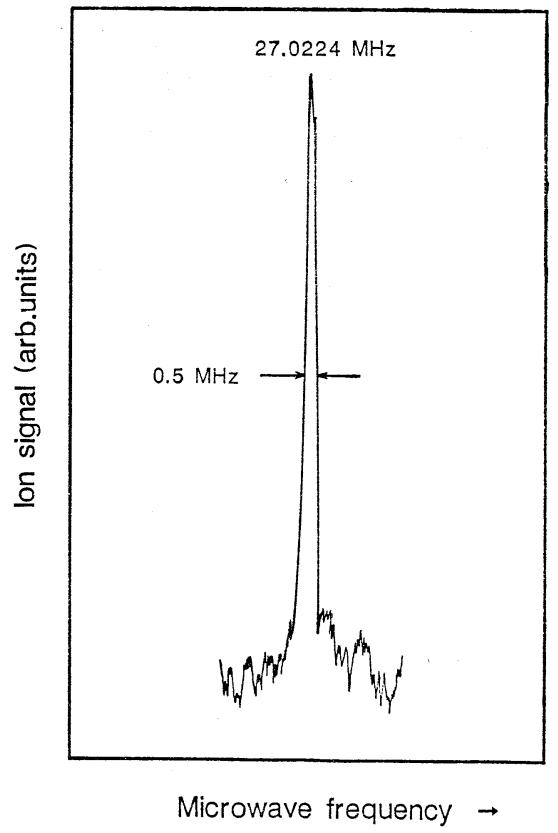

図 2 マイクロ波遷移のイオン化スペクトルの一例. 遷移は $6 \mathrm{~s} 34 \mathrm{p}^{3} \mathrm{P}_{1}{ }^{\circ}-6 \mathrm{~s} 34 \mathrm{~s}{ }^{1} \mathrm{~S}_{0}$.

H. M.))，特に高分解能が必要な場合以外無視できる. 一方マイクロ波との有限な相互作用時間 $\Delta T$ によるスペ クトル幅 $\Delta \nu_{T}$ は原理的に $1 / \Delta T$ で与えられるため, $\Delta T$
が $10 \mu \mathrm{s}$ としても $\Delta_{T}$ は $100 \mathrm{kHz}$ 程度となってしまい， 結局この相互作用時間 $\Delta T$ がマイクロ波遷移のスペク トル幅を決定する主な要因となることが判る。図 2 に示 したスペクトルの幅は約 $500 \mathrm{kHz}$ であるが，これは $\Delta T$ が 2 3 $\mu$ s 程度である他, クライストロンの不安定性や パルス電場の残留電場なぞの影響であると考えられる. より高いスペクトル分解能を得るためには以上の点を改 善するほかに，磁気シールドなどによる磁場の影響の除 去や，液体窒素或は液体へリウム温度で測定を行うこと によって黒体輻射の影響を低減するなど，装置の様々な 改良を行う必要がある。

\section{文献}

1) 例え汸 H. Maeda, Y. Mizugai, A. Suzuki and M. Takami: J. Phys. B22, L511 (1989).

2) 例えば T. R. Gentile, B. J. Hughey, D. Kleppner and T.W. Ducas: Phys. Rev. A42, 440 (1990).

(東大工 前田 遥, 鈴木篤之, 理研 高見道生) *

* Haruka MaEda and Atsuyuki SuzUKI, University of Tokyo, Hongo, Bunkyo-ku, Tokyo 113. Michio TAKAMI, Institute of Physical and Chemical Research (RIKEN), Hirosawa, Wako-shi, Saitama 351-01. 